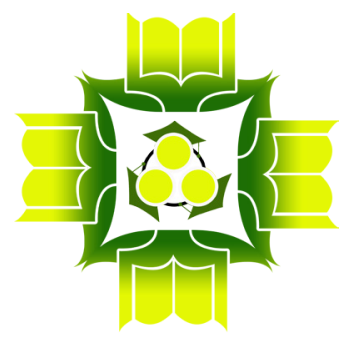

\title{
ASSOCIATIVE AND DISSOCIATIVE SOCIAL INTERACTION PATTERNS IN THE INCLUSION SCHOOL OF SD TAMAN MUDA IBU PAWIYATAN YOGYAKARTA
}

\author{
Wina Calista \\ STIT NU Sumber Agung OKU Timur \\ winacalista21@gmail.com \\ Mudiyono \\ STIT NU Sumber Agung OKU Timur \\ mudiyono05@gmail.com
}

\begin{abstract}
The background of this study is still the occurrence of rejection and disputes between regular students and students with special needs in inclusion schools. This certainly has an impact on student relationships in schools. Therefore, this study aims to describe the pattern of associative and dissociative interaction of regular students and students with special needs at SD Taman Muda Ibu Pawiyatan Yogyakarta. This type of research is qualitative research with a phenomenology approach. The result of this study is a pattern of associative interaction between regular students and students with special needs classified in the form of cooperation, assimilation, and accommodation. Cooperation is seen at the activities in the school. This form of assimilation between regular students and students with special needs is the planting of a tolerance attitude. The form of accommodation between regular students and students with special needs leads to a form of arbitration and tolerance. Dissociative interaction patterns between regular students and students with special needs are classified in patterns of competition, contravention, and conflict/strife. Competition occurs in academic competition and competition to be the best student. While the contravention which leads to rejection and the onset of displeased feelings hidden by students against the companion of students with special needs(shadow teacher). The conflict is dominated by students with special needs with emotional and behavioral disorders (unsociability disorder).
\end{abstract}

Keywords: Social Interaction Patterns, Associative, Dissociative. 


\begin{abstract}
Abstrak
Latar belakang penelitian ini yaitu masih terjadinya penolakan dan pertikaian antar siswa reguler dan siswa berkebutuhan khusus di sekolah inklusi. Hal ini tentu berdampak pada hubungan siswa di sekolah. Untuk itu penelitian ini bertujuan untuk mendeskripsikan pola interaksi asosiatif dan disosiatif siswa reguler dan siswa berkebutuhan khusus di SD Taman Muda Ibu Pawiyatan Yogyakarta. Jenis penelitian adalah penelitian kualitatif dengan pendekatan fenomenologi. Hasil penelitian ini adalah pola interaksi asosiatif antara siswa reguler dan siswa berkebutuhan khusus diklasifikasikan dalam bentuk kerjasama, asimilasi dan akomodasi. Kerjasama dilihat dari kegiatan yang ada di sekolah. Bentuk asimilasi antara siswa reguler dan siswa berkebutuhan khusus adanya penanaman sikap toleransi. Adapun bentuk akomodasi antara siswa reguler dan siswa berkebutuhan khusus mengarah pada bentuk arbitrase dan toleransi. pola interaksi disosiatif antara siswa reguler dan siswa berkebutuhan khusus diklasifikasikan dalam pola persaingan, kontravensi dan konflik/pertikaian. Persaingan terjadi dalam persaingan akademik dan persaingan menjadi siswa terbaik Sedangkan kontravensi yang mengarah pada penolakan dan timbulnya perasaan tidak suka yang disembunyikan oleh siswa terhadap pendamping siswa berkebutuhan khusus (shadow teacher). Adapun pertikaian/konflik yang terjadi didominasi oleh siswa berkebutuhan khusus dengan gangguan emosi dan perilaku (tunalaras).
\end{abstract}

Kata Kunci: Pola Interaksi Sosial, Asosiatif, Disosiatif.

\title{
INTRODUCTION
}

Social development in elementary school-age children is characterized by a wider relationship in addition to family and peers so that the wiggle room in social interaction will be expanded and expanded. Children will begin to be interested in the activities of their friends and the increasing willingness to be accepted into the group. The beginning of the child entering the school environment is the beginning of the child begins to know the school as a gathering place for children with all differences. Children at first do not know each other and then will establish social relations in school until outside the school (Djamarah,2011). A child's social development can be seen when the child begins to join a playgroup. From the playing group, usually will form light activities such as playing together. So that in the process of playing together, it is expected that children will and dare to interact with others around them(Matanari et al., 2020).

Social interactions that occur in schools can be in the form of relationships in cooperation, helping each other to relationships that lead to a conflict until 
disputes (Mahmud, 2015). So not all students can have a good interaction with their friends. This is because each student has different roles, positions, backgrounds such as family status, economy, religion, even differences in physical and ability (Kustawan, 2013). In the process of social interaction both in the community and school, children who have different physical and abilities are the dominant ones getting mistreated (Subini, 2014). Like normal children, those with physical abnormalities or obstacles become part of the perpetrator of social interaction itself. The existence of children who have physical disorders and obstacles as diverse as autistic children, deaf, homeless and others, can certainly affect them in interacting with others. For example, in deaf children who have communication limitations caused by hearing loss that will then become an obstacle in interacting.

Children with special needs also have the same rights and obligations to obtain education, study, and interact in school without discrimination. Law No. 20 of 2003 on the National Education System affirms the Government is obliged to conduct education democratically and fairly and not discriminate by upholding human rights, religious values, cultural values, and national diversity (Law No 20 year 2003 about National Education System). So far, children with special needs are identical to children who can only study in special education services or outstanding schools (SLB). It is unwittingly that this forms a wall of exclusive for children with special needs themselves. In contrast to more open inclusion, exclusionism is the tendency to separate from the environment. The existence of a wall of exclusivity can limit the interaction of children with special needs with regular children of their age so that groups of children with special needs are more likely to be alienated. To minimize the occurrence of this, the government has developed an inclusion school for students with special needs. In its implementation, public schools that get labeled as inclusion schools have several criteria such as teacher training in dealing with students with special needs, assessment training for students with special needs, schools have friendly facilities and can be reached by students with special needs and teachers are able to set examples to all regular students to have a sense of concern for others. So that students with special needs feel comfortable and safe while studying in school.

Inclusion education in Indonesia is as one of the efforts in realizing education for all. The existence of inclusion institutions at the elementary school education 
level shows how the role of people with disabilities in social interaction, because inclusion education provides a learning concept that allows all children to get the same educational rights regardless of the limitations that students have (Kustawan, 2013). Inclusion education, which refers to education for all, seeks to reach everyone without exception and also the government's efforts to minimize the gaps that occur between students with special needs in the educational environment.

Inclusion education has been agreed by many countries to be implemented in order to combat discriminatory treatment in the field of education. The implementation of inclusive education is based on international documents, namely the Universal Declaration of Human Rights in 1948, the United Nations Convention on the Rights of the Child in 1989, the World Declaration on Education for All, the Jomtien of 1990, the Standards Regulation on Equality of Opportunity for Persons with Disabilities in 1993, the Salamanca Statement and the Framework of Action on Special Needs Education in 1994 (Darma and Rusyidi, 2015).

Taman Muda Ibu Pawiyatan School is one of the schools that implements inclusion education starting from kindergarten, elementary, junior high, and high school listed in the decree of the Yogyakarta City Office. So in school, there are various kinds of children with special needs such as children with hearing impairment, deafness, deafness, to specific learning disorders. The existence of students with special needs as a minority in the school in which then merges with the regular students who are more numerous (majority) in one school.

At the elementary education level of inclusive school Taman Muda Ibu Pawiyatan has its own characteristic of applying mandatory smiles and saying "happy greetings" is aimed at creating a family environment so that students feel safe, comfortable in school without any feeling of lack of confidence from students. The school has many posters about student values affixed to each rung. In addition, primary school Taman Muda Ibu Pawiyatan also applies "among the system" with the motto Tut Wuri Handayani which recognizes that each child can not be separated from the interaction process in school. Primary school Taman Muda Ibu Pawiyatan also recognizes that each individual has their own uniqueness. 
From the preliminary study of interviews with shadow teachers, information was obtained that the diversity of students at primary school Taman Muda Ibu Pawiyatan Yogyakarta which sometimes the relationship between regular students and students with special needs can be well established such as helping each other, but the act of rejection of students with special needs until even physical disputes can not be denied can also occur between regular students and students with special needs (Observation, August 09, 2021). Based on the results of the initial research study where social interaction between regular students and special needs students who still occur negative interactions such as disputes then this is the basis of the author conducting research and analyzing in detail related patterns of social interaction of students that will be detailed in activities in school.

\section{METHODS}

This type of research is qualitative research with a phenomenology approach._Qualitative research in phenomenological approaches was conducted because researchers wanted to explore descriptive unresolved phenomena. From here, researchers in phenomenology attempted to enter and participate in the activities of the subjects studied. The phenomenology approach in this study aims to know the events and relationships to people in certain situations, so as to know how the pattern of associative and dissociative interaction of regular students and students with special needs; in the inclusion school of primary school SD Taman Muda Ibu Pawiyatan Yogyakarta. In this study, to determine the data source, researchers used purposive sampling techniques and snowball sampling (Arikunto, 2013).

The data sources in this study involved several parties who were objects in the study, namely four classroom teachers, one special companion teacher, two shadow teachers, and one Islamic religious teacher. As for the number of students with special needs who became the object of research as many as ten students. Testing the validity of the data in this qualitative study researchers used triangulacy techniques to test the validity of the data. Triangulacy techniques used are source triangulacy and methods (Sugiono,2017). Data analysis techniques used in this study include data reduction, data display, and conclusion drawing/ 
verification (Lexy J. Moleong,2007). Data collection techniques in this study use observations, interviews, and documentation (Suharsaputra, 2011).

\section{RESULTS AND DISCUSSION}

Primary school Taman Muda Ibu Pawiyatan is one of the inclusion schools in Yogyakarta. As an inclusion school, of course, students in the school are not only regular students but also students with special needs. The diversity of students with special needs at primary school SD Taman Muda Ibu Pawiyatan also consists of various types, such as autism, deafness, home deafness, and specific learning disorders.

Of the different types of students with special needs in inclusion schools of course, they have different patterns of adaptation and interaction according to the symptoms. Just as with children with hearing impairments are more likely to be less active in terms of interacting due to hearing loss in communication. In the journal Khamim Zarkasih Putro social interaction between students will open an opportunity to learn how to interact with fellow peers his age, to control social behavior, to develop skills and interests according to age, and to open each other when there are problems or feelings of the same (Khamim Zarkasih Putro,2015).

Social interactions which occured between individuals or groups are being control by the super-ego of the individual concerned so that his social behavior can be in accordance with the life of his group. This is because the individual's super-ego contains values, rules, or social norms that have been embedded in an individual's personality. Every human being has an instinct that encourages the occurrence of social behavior. Human instinct in this case is divided into two, namely the instinct to live and the instinct to die. The instinct to live means that people have constructive behavior that is useful behavior to establish cooperation with others. While the instinct to die means that humans have destructive behavior that can damage relationships between individuals (Santoso, 2010). The ability to interact with children consists of several things, namely: speaking well and politely, delivering messages with a speech, telling the events experienced, telling stories in front of the class, listening to people who are talking, calling and greeting peers, and taking the pattern of speech. Two-way communication is a means for children to learn to interact with adults 
and with peers and can also improve the ability to make friends and interact with peers positively. Indicators of communication skills in children as the core of social engineering skills are children greeting friends when meeting, children can communicate with friends in learning activities, children say help when asking for help, children listen to educator explanations, children ask educators in learning disorders, children listen to people who are talking, children can tell what children feel (Oktari et al., 2019).

The formation of emotional intelligence in children is determined by two factors, namely internal and external factors. Internal factors that affect the child's emotional intelligence are the child's physical and psychology, while external factors are in the form of stimulus and environment, including parental parenting. Parenting has a strong influence on the child's emotional development. Parenting is proven to have an influence on children's self-control, empathy, expressing and understanding feelings, controlling anger, independence, ability to adjust, being liked, ability to solve interpersonal problems, honesty, solidarity, friendliness, and respect (Nafi'ah \& Islakhudin, 2020). Based on the observation of the form of interaction between regular students and students with disabilities is then classified into associative and dissociative interaction patterns, namely:

\section{Associative Interaction Pattern Of Regular Students And Students With Special Needs In The Inclusion School Of SD Taman Muda Ibu Pawiyatan Yogyakarta}

In the process of associative interaction between regular students and students with special needs leads to a positive relationship. The associative relationship is then classified into several types of activities containing cooperation, assimilation, and accommodation as follows:

\section{Associative Interaction Patterns Lead To “Cooperation"}

As part of the social interaction process, cooperation has several forms such as harmony, help, and mutual assistance (Soekamto,2006). Therefore, cooperation between regular students and students with special needs at primary school SD Taman Muda Ibu Pawiyatan Yogyakarta is classified in several activities that lead to harmony, help, 
and mutual assistance. These activities may occur in the classroom or outside the classroom including:

\section{Class Picket}

Picket duty at primary school Taman Muda Ibu Pawiyatan is done every day, monday to Friday. Class pickets are done by students when the study hours are complete, so before going home first clear the class picket. Class pickets during the day are done by students so that in the morning students do not interfere with teaching and learning activities.

Based on the observations, the form of class picket cooperation between regular students and students with special needs is done by dividing picket assignments. This picket task is done in a mutual manner by regular students and students with special needs are also sometimes assisted by shadow teachers. So that students with special needs continue to participate in class picket activities like regular students. However, in carrying out picket activities, students with special needs must be reminded, notified until supervised. This aims to allow students with special needs to complete their picket tasks well. Students with special needs with impaired (paralyzed) pickets are replaced by their shadow teachers.

\section{Learning Process In The Classroom}

A harmonious relationship between teachers and learners is indispensable in the teaching and learning process. Effective interaction activities between teachers and learners will make it easier for learners to receive and learn the subject matter well (Fahri \& Qusyairi, 2019). Cooperation between regular students and students with special needs is established in the form of help, which is an attitude that teachers emphasize to all students in the classroom, especially to regular students. In this case, the teacher provides understanding to regular students to help students with special needs if they have difficulties in learning. This is because not all students with special needs have a shadow teacher accompanying them while studying in class. If the students with special 
needs have shadow teachers then all difficulties experienced by students with special needs will be helped.

There are some shadow teachers who do not accompany at the time of learning because students with special needs are considered cognitively able so that the shadow teachers only help the students' activities outside of study hours such as if students go to the toilet or rest. Therefore, the need for teachers in instilling a caring attitude to regular students to help, so that at a time when students with special needs need help at the time of learning not necessarily all teachers who help, but also regular students can help (Observation, August 12, 2021)

Forms of attitudes to help regular students with special needs such as helping deaf students prepare textbooks, helping deaf students to answer questions and writing, helping autistic students to focus on the teacher explaining the material, to working together to cut newspapers to make pulp.

\section{Group Discussion}

Cooperation in group discussions between regular students and special needs at SD Taman Muda Ibu Pawiyatan was conducted by dividing the assignment. In group discussion activities in the classroom students with special needs remain involved in one group with regular students. However, if students with special needs are accompanied by shadow teachers in group discussion activities. As shown in the picture above, cooperation is seen in group discussions between regular students, autistic students, and deaf students. Students with special needs with the assistance of shadow teachers help regular students to answer questions. However, it appears that deaf students are less participating in the discussion. So that deaf students are given the task to collect answer sheets and read the results of group discussion answers with the help of teachers.

However, regular students understand the situation. In the division of assignments in the discussion of regular student groups at primary school SD Taman Muda Ibu Pawiyatan, it appears that the regular 
students understand the abilities of students with special needs therefore the role of students with special needs is adjusted to their abilities.

\section{Rest Hours}

The rest time at primary school SD Taman Muda Ibu Pawiyatan Yogyakarta takes place during the first break time which is 09-20-09:35 WIB and the second break at 11:55-12:30 WIB. During school break hours, students make use of it with a variety of activities. As the observations have been made, at the time of the bell break hours some regular students and students with special needs such as together to go to the cafeteria to buy food, as did RR (regular students), TT (students with physical impairments) and RK (students with intellectual impairments) together go to the cafeteria and then eat together and occasionally RR feed each other. In addition, it appears OK (regular students) shared bread with PA (students with specific learning disorders) (Observation, August 25, 2021).

The togetherness between regular students and students with special needs is very closely intertwined during school break hours. This is shown by helping each other, sharing food, eating together until regular students do not hesitate to feed students with special needs. This shows that in his interactions at school at recess, regular students as students who do not group with only regular students.

\section{Clean Friday Activities}

Clean Friday activities are one form of habituation that is applied to students to be attached and become a character to the student itself must be done gradually by encouraging students to care about the environment from a small scope first, namely the scope of the class (Handayani et al., 2021). Clean Friday is one of the activities to clean the environment at SD Taman Muda Ibu Pawiyatan. This activity is conducted once a week on Fridays from 07:30 to 08:00 before the start of study hours. In Fridays' clean-up activities all students from grades 1-VI were involved in cleaning up the school environment. So that the form of cooperation in clean Friday activities conducted by regular students and students with 
special needs at primary school Taman Muda Ibu Pawiyatan Yogyakarta is in collaboration with mutual cooperation in cleaning the environment in schools in clean Friday activities.

Based on the observations on Friday activities clean regular students and students with special needs communal work to clean plastic waste in the pool and the schoolyard, sweep the school terrace and water plants. As seen in the picture above between LE (students with emotional, social, and behavioral disorders) and RA (regular students) work together to retrieve garbage that is pooled with a white stick while RA accommodates garbage collected using shovels. The OK (regular students) help RM (autistic students) dispose of the garbage while showing the type of organic and inorganic waste. Meanwhile, other students with special needs in clean Friday activities are assisted by shadow teachers to clean the school environment (Observation August 23, 2021)

\section{Associative Interaction Patterns Lead To "Assimilation"}

Assimilation is a cognitive process that occurs when a person integrates a new perception, concept, or experience into a scheme that is already in mind (Ahmad Yogi,2018). Assimilation is an advanced stage of social interaction that leads to positive relationships. Assimilation has the aim to reduce the differences between individuals and groups (Soekamto,2006). The assimilation at SD Taman Muda Ibu Pawiyatan Yogyakarta aims to reduce the occurrence of different stigmas between regular students and students with special needs both individually and in groups. Tolerance is the main thing instilled by teachers so that regular students and students with special needs can make good friends without discriminating (Nyi Indah Prasetio Interview, 02 August 2021). The findings in the field are those regular students can easily blend in with students with special needs regardless of differences.

The attitude of tolerance taught by teachers makes regular students and students with special needs easy to assimilate regardless of differences. In some of the regular student learning activities in a group, regular students ask students with special needs whether they 
have finished doing chores, playing together, joking and eating together during recess, helping each other if they need help.

\section{Associative Interaction Patterns Lead To "Accommodation"}

Accommodation is an attempt to defuse the occurrence of conflict with the aim of achieving a better relationship (Soekamto, 2006). According to (Santoso, Dinamika Kelompok, 2004, p. 69) that has several forms such as coercive, compromise, arbitration mediation, contemplation, tolerance, and stakemate.

From the observations, it is known that the form of accommodation in SD Taman Muda Ibu Pawiyatan at the time of the conflict leads to a form of arbitration and tolerance. Arbitration occurs because of the involvement of shadow teachers as intermediaries and helps resolve conflicts between regular students and students with special needs. Accommodation conducted by regular students at the time of a dispute with students with special needs is with tolerance and does not retaliate for actions taken by students with special needs. (Observation 07 September 2021). In addition, at the time of the dispute between regular students and students with special needs in the school field, shadow teachers immediately separated the dispute At the time of the conflict shadow teacher separated the students involved in the conflict and then asked to apologize to each other (Observation August 23, 2021).

\section{Dissociative Interaction Pattern Of Regular Students And Students With Special Needs At The Inclusion School Of primary school SD Taman Muda Ibu Pawiyatan Yogyakarta}

Dissociative interaction patterns are seen as a process of interaction that leads to disputes between individuals and groups to achieve certain goals (Soekamto,2006). Dissociative includes competition, contravention, and conflict (Abdulyani, 2007). Based on the above forms of dissociative interaction, the dissociative interaction between regular students and students with special needs at SD Taman Muda Ibu Pawiyatan Yogyakarta can be classified into several parts, namely: 


\section{Dissociative Interaction Leads To "Competition"}

Competition is a social process, in which competing individuals or groups of people seek to profit through areas of life that at some time become the center of public attention (both individuals and groups of people) by attracting public attention or by sharpening existing prejudices, without the use of threats or violence (Wakhid,2017). Competition is characterized by competing against each other or competing between individuals or between groups without any element of threat or violence to obtain an expected goal. The forms of competition include economic competition, competition for positions and roles, to competition of race or ability (Soekamto, 2006). Based on the observations that have been made obtained data that competition between regular students and students with special needs occurs in several things, including:

\section{Academic Competition}

Competition or competition is a feeling where a person will feel a motivation not to lose to other individuals or groups (Wahyudi and Kurniasih ,2020). Academic competition between regular students and students with special needs at primary school SD Taman Muda Ibu Pawiyatan is based on the presence of students with special needs who have intellectual abilities such as regular students. In addition, competition between regular students and students with special needs at primary school SD Taman Muda Ibu Pawiyatan also occurs because there are students with special needs, namely AN (deaf) who are intellectually the same as regular students. Nevertheless, AN has intellectual abilities like other regular students. Even children with special needs excel and often participate in the Olympics. Therefore, the learning process in AN class is not accompanied by shadow teacher.

Based on the observation of competition between regular students and AN as students with special needs are seen when the teacher goes around and checks the answer sheet on each student. When the teacher checks the AN answer sheet the results are correct, while the SA answer sheet (regular student) sitting next to AN is incorrect. Then the teacher 
asked SA to double-check the answer without seeing AN's answer sheet. That's when SA showed a slightly irritated facial expression and showed a heavy-hearted attitude when helping AN show the pages of assignments in the printed book. Competition in academic matters also occurs when teachers share the results of the students' daily tests. Where there are regular students who get a smaller score than students with special needs, which then makes the subject matter among regular students (Observation, August 27, 2021).

\section{Competition To Be The Best Student In The Classroom}

In addition to competition in academic matters, between regular students and students with special needs also compete to achieve the best student predicate. The coronation as the best student was only done in grade IV on the initiative of the grade IV teacher. With the coronation as the best student in grade, IV can certainly increase the motivation of students to be better and can also train students to familiarize themselves with discipline in everything. But to be the best student of course, each student tries to be the best among his other friends. Indirectly students compete to be the best.

According to that students' learning motivation can arise due to intrinsic factors, in the form of desire and desire to succeed and the encouragement of learning needs, expectations of goals. While the extrinsic factor is the presence of awards and interesting learning environment.

\section{Dissociative Interaction Leads To "Contravention"}

Contravention is a social process that is between competition and conflict or conflict. In addition, contravention can also be interpreted as behavior that shows differences about various things between individuals or groups to cause conflict (Mahmud,2015). Contravention can arise in various forms such as rejection, hidden dislikes, threats, and intimidation (Rohman,2009). 
Based on the classification of the above forms of contravention attitudes, the pattern of interaction that leads to the attitude of contravention between regular students and students with special needs at primary school SD Taman Muda Ibu Pawiyatan Yogyakarta leads to rejection and feelings of dislike that are hidden.

\section{Contravention Leads To "Rejection"}

Contravention behavior that leads to rejection occurs when teachers divide discussion groups during classroom learning. This is seen by some regular students doing refusal if they have to get a group member with special needs students. The refusal of regular students to students with special needs is one of the underlying divisions of group discussion members entirely conducted by teachers. According to regular students, the refusal is motivated by the abilities possessed by students with special needs themselves. Regular students assume that in group discussions all are done alone without the help of students with special needs to find answers. So it can result in low group value obtained at the time of discussion.

A person who has a high level of empathy always shows a positive attitude towards others and avoids actions or behaviors that can hurt and harm others. From the study, it can be known that bullies do their actions because they have low empathy abilities (Delita Mandasari,2020). The attitude that regular students have toward special needs students is what regular students see and feels about the limitations of students with special needs both physically, socially-emotionally and intelligently The attitude that regular students have toward special needs students is what regular students see and feels about the limitations of students with special needs both physically, socially-emotionally and intelligently (Yudhayanto,2015).

In this case, regular students can show an attitude in the form of a positive attitude or a negative attitude. The positive attitude that exists in regular students is that regular students will tend to accept the presence of students with special needs with some shortcomings both 
physically, socially-emotional and intelligently, so that when students with special needs experience difficulties regular students will always be willing to help and care about the lack of students with special needs, conversely if the attitude in regular students is negative towards students with special needs then regular students will reject and cannot accept students with special needs with their shortcomings physically, socially-emotional and intelligently so that what is done is avoidance and rejection in the environment. The association allows students with special needs to get bullied both physically, verbally, body cues, and groups (Hasanah et al., 2015).

\section{Dissociative Interaction Leads To Disputes}

From the observation of conflicts that occur between regular students and students with special needs (unsociability disorder) such as during class learning some regular students remind AJ (unsociability disorder) to pay a fine of five hundred rupiah to the teacher for buying noodles with plastic wrap, AJ refused to pay the fine and it made AJ angry and then AJ kicks the table and chairs in the class and then ran away from class at the time the learning is being held (Observation, August 23, 2021). In addition, conflicts also occur during recess when SY (regular students) reminded LE (unsociability disorder) not to buy instant noodles, considering students are prohibited from buying instant noodles at school. Feeling unacceptable with the reprimand angered LE. LE's anger was vented by throwing SY with a rice box and clawing SY's hand.

The occurrence of disputes or conflicts between regular students and students with special needs at SD Taman Muda Ibu Pawiyatan Yogyakarta is dominated by regular students and deaf students. The type of unsociability disorder that causes students easily angered and troubled to calm their emotions. Therefore, students who have impaired disorder usually show deviant behavior that is not in accordance with the norms and rules that apply around it. 
The most common problems shown by children with emotional or behavioral disorders are hitting, fighting, taunting, shouting, refusing to comply with other people's requests, crying, damaging, and so on. When reviewed from physical development, students with unsociability disorder have no differences to regular students (Melchioriyusni, 2013). This is in line with the opinion of Nafsiah Ibrahim in the journal Aini Mahabbati who said that emotional and behavioral disorders in elementary school-age children are harder to detect than other types of special needs students (Mahabbati, 2006).

From conflicts that occur between regular students and students with unsociability disorder caused an impact on others, such as damaging to physically injuring. If it is associated with the opinion of Aini Muhabbati that the type of disorder that has a direct impact on others for the actions performed is called externalizing behavior. Externalize behavior which is one of the characteristics possessed by children who have emotional and behavioral disorders or is called unsociability disorder (Mahabbati, 2006). This, social interactions that are negative in elementary schoolage students in school can have an impact on behavior that does not adhere to school rules, interactions at home, assignments from teachers, isolation, hostility, and will have an impact on learning achievement to be achieved (Adyatma, Mulyanto, and Tahyudin,2020).

\section{CONCLUSION}

From the results of the study entitled associative and dissociative interaction patterns of regular students and students with special needs at the inclusion school of SD Taman Muda Ibu Pawiyatan Yogyakarta, the following conclusions can be drawn: First, the pattern of associative interaction between regular students and students with special needs at SD Taman Muda Ibu Pawiyatan Yogyakarta is divided into patterns of cooperation, assimilation, and accommodation. Cooperation includes class picket activities, cooperation in classroom learning, group discussions, school break hours, clean Friday activities, and dance arts activities. While assimilation between regular students and students with special needs aims to reduce different stigmas. In the process of assimilation, there is an 
attitude of tolerance to provide equal opportunities between regular students and students with special needs. Accommodation between regular students and students with special needs leads to a form of arbitration and tolerance. Second, the pattern of dissociative interaction between regular students and students with special needs at primary school SD Taman Muda Ibu Pawiyatan Yogyakarta is classified in the form of competition, contravention, and conflict/ strife. Competition occurs in the form of academic competition and competition to become the best students in the classroom. The forms of contravention between regular students and students with special needs include contraventions that lead to rejection and the onset of feelings of dislike hidden by students against the companion of students with special needs (shadow teacher). Meanwhile, disputes/conflicts that occur between regular students and students with special needs dominantly occur in students with emotional and behavioral disorders (unsociability disorder). 


\section{REFERENCES}

Abdulyani. (2007). Sosiologi, Skematika, Teori dan Terapan. PT Bumi Aksara.

Adyatma, R. T., Mulyanto, \& Tahyudin, D. (2020). Interaksi Sosial Peserta Didik Di Lingkungan Sekolah Dalam Pembentukan Karakter Di SMA Negeri 2 Kayuagung1. NUSANTARA: Jurnal Ilmu Pengetahuan Sosial, 7(2), 301314. https:/ / doi.org/10.31604/jips.v7i2.2020

Ahmad Yogi. (2018). Proses Asimilasi dan Akomodasi Mahasiswa Dalam Menyelesaikan Geometri. Prosiding Seminar Nasional, 4(1).

Arikunto. (2013). Prosedur Penelitian (Suatu Pendekatan Praktik). Rineka Cipta.

Darma, I. P., \& Rusyidi, B. (2015). Pelaksanaan Sekolah Inklusi Di Indonesia. Proseding KS: Riset \& PKM, 2(2), 147-300.

Delita Mandasari. (2020). Empati Siswa Reguler, Iklim Sekolah dan Perilaku Perundungan Terhadap Siswa Berkebutuhan Khusus Disekolah Inklusif. Psikoborneo:Jurnal Imiah Psikologi, Volume 4(No 2). https:/ / doi.org/DOI: 10.30872/psikoborneo

Djamarah, S. B. (2011). Psikologi Belajar. Rineka Cipta.

Fahri, L. M., \& Qusyairi, L. A. H. (2019). Interaksi Sosial Dalam Proses Pembelajaran. PALAPA : Jurnal Studi Keislaman Dan Ilmu Pendidikan, 7(1), 149-166.

Handayani, S., Jamaludin, U., \& Suparno. (2021). Building The Environmental Care Charakter Through Mutual Cooperation Activities At SDN Unyur. PRIMARY: Jurnal Pendidikan Guru Sekolah Dasar, 10(1). https:/ / doi.org/ http:/ /dx.doi.org/10.33578/jpfkip.v10i1.8019

Hasanah, U., Ni'matuzahroh, \& Nurhamidi, Y. (2015). Sikap Siswa Reguler Terhadap Siswa Berkebutuhan Khusus Dan Kecenderungan Bullying Di Kelas Inklusi. UNISIA, XXXVII(82).

Khamim Zarkasih Putro. (2015). Pengaruh Pola Asuh Dan Interaksi Teman Sebaya Terhadap Kecerdasan Emosional Anak Di Ra Arif Rahman Hakim Yogyakarta. Al-Athfal: Jurnal Pendidikan Anak, 1(2).

Kustawan, D. (2013). Model Implementasi Pendidikan Inklusi Ramah Anak. PT Luxima Metro Media. 
Lexy J. Moleong. (2007). Metodologi Penelitian Kualitatif. Rosdakarya.

Mahmud. (2015). Pendidikan Lingkungan Sosial Budaya. PT Remaja Rosdakarya.

Matanari, C., Gaol, R. L., \& Simarmata, E. (2020). Hubungan Pendidikan Karakter Terhadap Perkembangan Sosial Anak Sekolah Dasar. Jurnal EDUCATIO, 6.

Melchioriyusni, Zikra, \& Azrul Said. (2013). Interaksi Sosial Siswa dengan Kelompok Teman Sebaya di Sekolah dan Implikasinya terhadap Pelayanan BK. Jurnal Konseling Dan Pendidikan, 1(2), 102-108.

Nafi'ah, S. A., \& Islakhudin, M. (2020). Pengaruh Rombongan Belajar Siswa Terhadap Perkembangan Kognitif Sosial Peserta Didik Di MI Ma'arif Ngampedento Salaman Kabupaten Magelang Jawa Tengah. Elementary : Islamic Teacher Journal, 8(1).

Oktari, R., Nurlaili, N., \& Syarifin, A. (2019). Kesulitan Anak Usia Dini Dalam Berinteraksi Sosial Di TK Negeri 09 Bengkulu Selatan.

Rohman, A. (2009). Sosiologi. Intan Perwira.

Santoso. (2010). Teori Psikologi Sosial. PT Refika Aditama.

Soekamto. (2006). Sosiologi Suatu Pengantar. PT Raja Grafindo.

Subini, N. (2014). Pengembangan Pendidikan Inklusi Berbasis Potensi. Maxima.

Sugiono. (2017). Metodologi Penelitian Pendidikan. Alfabeta.

Suharsaputra, U. (2011). Metode Penelitian Kualitatif, kuantitatif dan Tindakan Kelas. PT Refika Aditama.

Wahyudi, D., \& Kurniasih, N. (2020). Urgensi Prinsip Kerjasama Dan Kompetisi Dalam Pengelolaan Pengajaran. RAUDHAH :Proud To Be Professional JurnalTarbiyah Islamiyah, Volume 5(2).

Wakhid, A., Andriani, N. S., \& Saparwati, M. (2017). Kemampuan Interaksi Sosial Siswa Usia 10-12 Tahun Di Ungaran. Jurnal Keperawatan, 5(2), 87-90.

Yudhayanto, R. (2015). Interaksi Sosial Siswa Difabel Dalam Sekolah Inklusi di SMA Negeri 8 Surakarta. SOSIALITAS: Jurnal Ilmiah Pend. Sos Ant, 5(2). 